\title{
OUTCOME OF PATIENTS ADMITTED WITH EXERTIONAL HEAT RELATED ILLNESS IN INTENSIVE CARE UNIT OF TERTIARY CARE HOSPITAL
}

\author{
Amatya $B R^{1^{*}}$, Shrestha $B^{2}$, Rayamajhi $M^{1}, K C N B^{3}$, Karki $P^{4}$
}

\section{Affiliation}

1 Lecturer, Department of Anaesthesiology, Nepalese Army Institute of Health Sciences, Kathmandu

2. Lecturer, Department of Community Medicine, Nepalese Army Institute of Health Sciences, Kathmandu

3. Professor, Department of Anaesthesiology, Nepalese Army Institute of Health Sciences, Kathmandu

4. Medical officer, Shree Birendra Hospital

\section{ARTICLE INFO}

Article History

Received : 10 July, 2018

Accepted : 6 November, 2018

Published : 31 December, 2018

(C) Authors retain copyright and grant the journal right of first publication with the work simultaneously licensed under Creative Commons Attribution License CC - BY 4.0 that allows others to share the work with an acknowledgment of the work's authorship and initial publication in this journal.

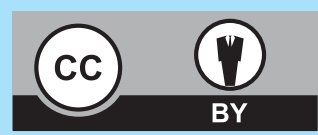

ORA 83

DOI: $\underline{10.3126 / \text { bjhs.v3i3.22168 }}$

\author{
* Corresponding Author \\ Dr. Bishwo Ram Amatya \\ Lecturer \\ Department of Anaesthesiology \\ Nepalese Army Institute of Health Sciences \\ Email: biswa156@gmail.com \\ ORCID: https://orcid.org/0000-0002-8527-8858
}

\section{Citation}

Amatya BR, Shrestha B, Rayamajhi M, KC NB, Karki P. Outcome of Patients Admitted with Exertional Heat Related IIIness in Intensive Care Unit of Tertiary Care Hospital. BJHS 2018;3(3)7:524 - 527.

\section{ABSTRACT}

\section{Introduction}

Exertional heat related illness particularly heat stroke is very common life threatening condition that frequently occur in young military trainee due to high ambient temperature and humidity.

\section{Objective}

The study was undertaken to identify its outcome in recruits admitted in intensive care units of military tertiary care hospital.

\section{Methods}

An observational cross-sectional descriptive study was done among those recruits admitted in Intensive Care Unit of military tertiary care hospital with diagnosis of heat related illness from June 2016 to August 2017 A.D. Data based on hospital case records were collected and analyzed using SPSS version 22. Primary outcome studied was mortality. Secondary outcomes studied were length of stay in ICU, hospital and on ventilator.

\section{Results}

Out of 17 recruits, 12 were diagnosed as heat exhaustion and 5 were diagnosed as heat stroke. SOFA score for heat stroke and heat exhaustion patients ranged from 2-16 and 02 with respective mortality rate $7-95 \%$ and $0-7 \%$. APACHE II score for heat stroke and heat exhaustion patients ranged from $5-33$ and $0-5$ with respective mortality rate $5.80-73 \%$ and $0-5.80 \%$. There was no mortality among 12 heat exhaustion patients. Out of 5 heat stroke patients, 3 died with $60 \%$ mortality rate. Heat stroke patients had maximum stay of 4 days in ICU, hospital for 5 days and ventilator for 4 days.

\section{Conclusions}

Exertional heat related illness is common in young military trainee with heat exhaustion and heat stroke being common causes for ICU admission. Heat stroke has higher mortality rate due to multiple organ dysfunction.

\section{KEYWORDS}

Heat stroke, military recruits, outcome 


\section{INTRODUCTION}

Heat related illness (HRI) due to high ambient temperature and humidity are very common in tropical region of Nepal during summer. ${ }^{1}$ Exertional heat related illness particularly heat stroke is a life threatening condition that frequently occur in young military trainee. ${ }^{2,3,4}$

Heat related illness occurs when there is failure of thermoregulatory response to maintain core body temperature between $36^{\circ}-38^{\circ} \mathrm{C} .^{5}$ Types of HRI are heat cramps (muscle cramping), heat syncope (fainting), heat exhaustion (hypotension followed by collapse) and heat stroke which is the severe form where core body temperature is $>40^{\circ} \mathrm{C}$ leading to central nervous system dysfunction. ${ }^{6}$ Mortality rate of heat stroke varies from $10-70 \%$ with persistent neurological damage in $7-20 \%$ of survivors. ${ }^{6}$ Heat stroke can be non- exertional or exertional resulting from excessive heat production during strenuous activity.,

Every year many recruits suffer from HRI at Nepali Army training centre. The objective of the study was to identify clinical outcomes of exertional heat related illness in those recruits who were admitted in ICU of military tertiary care hospital.

\section{METHODS}

After an ethical approval of Institutional Research Committee (IRC), an observational cross-sectional descriptive study was conducted among those recruits involved in military training at recruit training centre of Nawalparasi who were admitted in Intensive Care Unit (ICU) of military tertiary care hospital with the diagnosis of exertional heat related illness (HRI) from June 2016 to August 2017 A.D.

Inclusion criteria were all male military recruits involved in long distance running during their training in monsoon season from June to August, referred to ICU of military tertiary care hospital with signs \& symptoms of exertional HRI like heat cramps, heat syncope, heat exhaustion and heat stroke. All other military recruits with diagnosis of non exertional heat related illness were excluded. After stratified random sampling, data were collected based on hospital case records. Out of 83 soldiers who have HRI in 2 years, 17 were referred and admitted to ICU of military tertiary care hospital. Diagnosis was made based on clinical presentations. Baseline clinical and investigation data were obtained from individual case records included in the study. Clinical variables (Table 3) such as body temperature, heart rate, respiratory rate, mean arterial pressure and Glasgow Coma Scale (GCS) were noted. Major outcome variables (Table 4) such as complete blood count, coagulation profile, arterial blood gas analysis, liver function tests, renal function tests and hemodynamic stability were obtained. Predictor variables (Table 3 and Table 4) obtained were temperature, respiratory rate, heart rate, mean arterial pressure, use of ionotropes/vasopressors (Noradrenaline/Dopamine), total leukocyte count, hematocrit, platelet count, serum creatinine, serum sodium, serum potassium, bilirubin, arterial $\mathrm{pH}, \mathrm{PO} 2 / \mathrm{FiO} 2$ ratio, arterial bicarbonate, GCS and urinary output. Based on predictor variables, severity of illness for outcome prediction was assessed within $24 \mathrm{hr}$ of diagnosis of heat related illness using Acute Physiology and Chronic Health Evaluation (APACHE) II and Sequential Organ Failure assessment (SOFA) scoring system. All the data were entered and analysis was done using Statistical Package for Social Sciences (SPSS) version 22. Primary outcome studied was mortality or discharged after improvement. Secondary outcomes studied were length of ICU stay, length of hospital stay and number of days on ventilator.

\section{RESULTS}

Out of the 17 recruits, 12 (70.58\%) was diagnosed as heat exhaustion with $8(66.66 \%)$ in 2016 A.D. and $4(33.33 \%)$ in 2017 A.D. whereas remaining 5 recruits $(29.41 \%)$ was diagnosed as heat stroke with $3(60 \%)$ in 2016 A.D. and 2 (40\%) in 2017 A.D. (Table 1)

$\begin{aligned} & \text { Table 1: Frequency distribution of HRI admitted in ICU in } \\ & \text { 2016-2017 A.D. }\end{aligned}$
$\begin{array}{lccc}\text { Types of HRI admitted } & 2016 \text { A.D } & 2017 \text { A.D. } & \text { TOTAL } \\ \text { Heat Exhaustion (HE) } & 8 & 4 & 12 \\ \text { Heat Stroke (HS) } & 3 & 2 & 5\end{array}$

Out of the 12 heat exhausted patients, no one had mortality thereby all improved and discharged. Out of 5 heat stroke patients, three died with $60 \%$ mortality rate. (Table 2 )

\begin{tabular}{|c|c|c|c|c|}
\hline Types of HRI admitted & 2016 A.D & 2017 A.D. & TOTAL & Mortality Rate (\%) \\
\hline Heat Exhaustion (HE) & 0 & 0 & 0 & 0 \\
\hline Heat Stroke (HS) & 1 & 2 & 3 & 60 ( 3 out of 5 ) \\
\hline
\end{tabular}

Table 3: Clinical variables of HRI admitted in ICU in 2016-2017 A.D.

\begin{tabular}{|c|c|c|c|c|c|c|}
\hline & ICU Diagnosis & Temperature $\left({ }^{\circ} \mathrm{F}\right)$ & $\begin{array}{l}\text { Mean arterial pressure } \\
\text { /MAP }(\mathrm{mm} \text { of } \mathrm{Hg})\end{array}$ & $\begin{array}{l}\text { Heart Rate } \\
\text { (bpm) }\end{array}$ & $\begin{array}{c}\text { Respiratory } \\
\text { Rate (per min) }\end{array}$ & $\begin{array}{l}\text { Glasgow Coma } \\
\text { Scale (GCS) }\end{array}$ \\
\hline & Heat stroke & 101.00 & 55.00 & 120.00 & 30.00 & 8.00 \\
\hline & Heat Exhaustion & 99.00 & 68.00 & 84.00 & 16.00 & 14.00 \\
\hline & Heat stroke & 101.00 & 65.00 & 100.00 & 24.00 & 13.00 \\
\hline & Heat stroke & 100.00 & 67.00 & 94.00 & 20.00 & 13.00 \\
\hline & Heat Exhaustion & 99.60 & 70.00 & 84.00 & 12.00 & 14.00 \\
\hline & Heat Exhaustion & 98.60 & 67.00 & 88.00 & 16.00 & 13.00 \\
\hline & Heat Exhaustion & 100.60 & 66.00 & 76.00 & 20.00 & 13.00 \\
\hline & Heat Exhaustion & 99.60 & 72.00 & 84.00 & 20.00 & 14.00 \\
\hline & Heat stroke & 102.00 & 60.00 & 130.00 & 30.00 & 3.00 \\
\hline & Heat stroke & 101.00 & 58.00 & 126.00 & 36.00 & 3.00 \\
\hline & Heat Exhaustion & 100.00 & 65.00 & 72.00 & 16.00 & 14.00 \\
\hline & Heat Exhaustion & 99.60 & 68.00 & 76.00 & 16.00 & 15.00 \\
\hline & Heat Exhaustion & 100.60 & 66.00 & 72.00 & 16.00 & 15.00 \\
\hline & Heat Exhaustion & 100.00 & 70.00 & 80.00 & 16.00 & 15.00 \\
\hline & Heat Exhaustion & 99.40 & 72.00 & 84.00 & 16.00 & 15.00 \\
\hline & Heat Exhaustion & 100.20 & 74.00 & 86.00 & 16.00 & 15.00 \\
\hline & Heat Exhaustion & 100.40 & 72.00 & 90.00 & 16.00 & 15.00 \\
\hline \multirow{2}{*}{525} & \multicolumn{6}{|c|}{ Birat Journal of Health Sciences } \\
\hline & \multicolumn{2}{|c|}{ Vol.3/No.3/Issue 7/ Sep - Dec 2018} & \multicolumn{4}{|c|}{ ISSN: 2542-2758 (Print) 2542-2804 (Online) } \\
\hline
\end{tabular}




Table 4: Outcome variables of HRI admitted in ICU in 2016-2017 A.D.
\begin{tabular}{|l|c|r|r|r|r|r|r|r|r|c|}
\hline \multicolumn{1}{|c|}{ ICU Diagnosis } & PaO2/FiO2 & HCO3(mEq/L) & \multicolumn{1}{c|}{ pH } & Na(mEq/L) & K(mEq/L) & Cr(mg/dl) & $\begin{array}{l}\text { Bilirubin } \\
\text { (mg/dl) }\end{array}$ & Hematocrit & TLC(cmm) & Platelet(cmm) \\
\hline Heat stroke & 288.00 & 18.00 & 7.22 & 139.00 & 3.50 & 1.90 & 0.60 & 32.00 & 14300 & 175,000 \\
\hline Heat Exhaustion & 350.00 & 26.00 & 7.42 & 142.00 & 4.00 & 0.60 & 1.00 & 36.00 & 11200, & $1,78,000$ \\
\hline Heat stroke & 224.00 & 24.00 & 7.39 & 142.00 & 3.70 & 1.60 & 1.20 & 34.00 & 13550 & 164,000 \\
\hline Heat stroke & 288.00 & 26.00 & 7.42 & 138.00 & 3.20 & 1.40 & 1.10 & 36.00 & 12880 & 170,000 \\
\hline Heat Exhaustion & 326.00 & 22.00 & 7.36 & 138.00 & 3.60 & 0.80 & 0.80 & 40.00 & 11,000 & $1,64,000$ \\
\hline Heat Exhaustion & 346.00 & 23.00 & 7.38 & 136.00 & 3.50 & 0.60 & 0.80 & 44.00 & 10,800 & $1,66,000$ \\
\hline Heat Exhaustion & 300.00 & 20.00 & 7.33 & 140.00 & 3.80 & 1.00 & 0.60 & 39.00 & 10,400 & $1,74,000$ \\
\hline Heat Exhaustion & 348.00 & 24.00 & 7.39 & 138.00 & 3.60 & 0.80 & 0.80 & 33.00 & 10,800 & $1,52,000$ \\
\hline Heat stroke & 92.00 & 20.00 & 7.33 & 109.00 & 2.70 & 2.40 & 0.30 & 30.00 & 14500 & $<75,000$ \\
\hline Heat stroke & 106.00 & 22.00 & 7.34 & 126.00 & 2.40 & 2.80 & 0.80 & 28.00 & 13800 & 90,000 \\
\hline Heat Exhaustion & 366.00 & 25.00 & 7.41 & 140.00 & 3.80 & 1.00 & 0.60 & 45.00 & 11,000 & $1,76,000$ \\
\hline Heat Exhaustion & 436.00 & 26.00 & 7.42 & 140.00 & 3.80 & 1.00 & 0.60 & 36.00 & 8000 & 168,000 \\
\hline Heat Exhaustion & 427.00 & 28.00 & 7.44 & 138.00 & 3.60 & 0.80 & 0.80 & 39.00 & 7800 & 172,000 \\
\hline Heat Exhaustion & 448.00 & 27.00 & 7.43 & 144.00 & 4.20 & 0.80 & 1.00 & 42.00 & 7600 & $1,78,000$ \\
\hline Heat Exhaustion & 456.00 & 26.00 & 7.45 & 142.00 & 4.00 & 0.60 & 1.00 & 33.00 & 6400 & $1,58,000$ \\
\hline Heat Exhaustion & 444.00 & 24.00 & 7.42 & 136.00 & 3.50 & 0.60 & 0.80 & 45.00 & 6000 & $1,60,000$ \\
\hline Heat Exhaustion & 452.00 & 25.00 & 7.46 & 142.00 & 4.00 & 0.80 & 0.60 & 48.00 & 7200 & $1,76,000$ \\
\hline
\end{tabular}

Severity of HRI was studied by using SOFA and APACHE II scoring system (Table 5 and Table 6). Out of 12 Heat exhaustion patients (Table 5), six has zero SOFA and APACHE Il scores.

Table 5: Mortality prediction of HE by severity of illness
using SOFA and APACHE II Scores
\begin{tabular}{|c|c|c|c|c|}
\hline S.N & $\begin{array}{c}\text { SOFA } \\
\text { Score of } \\
\text { HE }\end{array}$ & $\begin{array}{c}\text { Predicted } \\
\text { Mortality } \\
\text { rate (\%) }\end{array}$ & $\begin{array}{c}\text { APACHE II } \\
\text { Score of HE }\end{array}$ & $\begin{array}{c}\text { Predicted } \\
\text { Mortality } \\
\text { rate (\%) }\end{array}$ \\
\hline 1 & 2.00 & 7.00 & 5.00 & 5.80 \\
\hline 2 & 2.00 & 7.00 & 5.00 & 5.80 \\
\hline 3 & 2.00 & 7.00 & 5.00 & 5.80 \\
\hline 4 & 2.00 & 7.00 & 5.00 & 5.80 \\
\hline 5 & 2.00 & 7.00 & 5.00 & 5.80 \\
\hline 6 & 2.00 & 7.00 & 5.00 & 5.80 \\
\hline
\end{tabular}

Table 6: Mortality prediction of HS by severity of illness

\begin{tabular}{|c|c|c|c|c|}
\multicolumn{5}{|c|}{ Using SOFA and APACHE II Scores } \\
\hline S.N. & $\begin{array}{c}\text { SOFA } \\
\text { Score of } \\
\text { HS }\end{array}$ & $\begin{array}{c}\text { Predicted } \\
\text { Mortality } \\
\text { rate (\%) }\end{array}$ & $\begin{array}{c}\text { APACHE II } \\
\text { Score of HS }\end{array}$ & $\begin{array}{c}\text { Predicted } \\
\text { Mortality } \\
\text { Rate (\%) }\end{array}$ \\
\hline 1 & 9.00 & 33.00 & 18.00 & 33.00 \\
\hline 2 & 5.00 & 20.00 & 7.00 & 7.60 \\
\hline 3 & 2.00 & 7.00 & 5.00 & 5.80 \\
\hline 4 & 16.00 & 95.00 & 33.00 & 73.00 \\
\hline 5 & 15.00 & 95.00 & 30.00 & 70.00 \\
\hline
\end{tabular}

The mean SOFA scores (Table 7) for heat stroke patients were $9.40 \pm 6.10$ with predicted mortality rate of $50 \%$. The mean SOFA score for heat exhaustion patients was $1 \pm 1.04$ with predicted mortality rate of $3.50 \%$. The mean APACHE II scores (Table 7) for heat stroke patients were $18.60 \pm 12.81$ with predicted mortality rate of $37.88 \%$. The mean APACHE II score for heat exhaustion patients was $2.50 \pm 2.61$ with predicted mortality rate of $2.90 \%$. The common organ systems involved were neurological $(64.70 \%)$, cardiorespiratory (29.41\% patients) and renal $(29.41 \%)$ with $100 \%$ involvement of these organ systems in heat stroke.

\begin{tabular}{|l|c|c|c|c|}
\hline Types of HRI & $\begin{array}{c}\text { Mean SOFA } \\
\text { Score } \pm \text { SD }\end{array}$ & $\begin{array}{c}\text { Predicted } \\
\text { Mortality } \\
\text { Rate (\%) }\end{array}$ & $\begin{array}{c}\text { Mean APACHE } \\
\text { II Score } \pm \text { SD }\end{array}$ & $\begin{array}{c}\text { Predicted } \\
\text { Mortality } \\
\text { rate (\%) }\end{array}$ \\
\hline Heat Exhaustion & $1 \pm 1.04$ & 3.50 & $2.50 \pm 2.611$ & 2.90 \\
\hline Heat Stroke & $9.40 \pm 6.10$ & 50 & $18.60 \pm 12.818$ & 32.53 \\
\hline
\end{tabular}

Among those one died in 2016 (33.33\%) where as two (66.66\%) died in 2017. The secondary outcome of heat related illness (Table 8 ) was studied in terms of mean ICU stay, mean Hospital stay and mean Ventilator stay. The mean ICU stay among HRI patients was $2.44 \pm 0.85$ SD with maximum stay of four days in one $(5.60 \%)$ heat stroke patient and minimum stay of one day $(16.7 \%)$. The mean hospital stay among HRI patients was $3.28 \pm 1.07$ SD with maximum stay of five days in one heat stroke patient $(5.60 \%)$ and minimum stay of two days (11.10\%). The mean stay on ventilator among HRI patients all being those of heat stroke was $0.39 \pm 0.97$ day with maximum stay for four days in one heat stroke patient (5.60\%) and minimum stay for one day in three heat stroke patients (16.70\%).

Table 8: Secondary outcome of Heat related illness
\begin{tabular}{|l|c|c|c|}
\hline Types of HRI & $\begin{array}{c}\text { Mean ICU } \\
\text { stay } \pm \text { SD }\end{array}$ & $\begin{array}{c}\text { Mean } \\
\text { Hospital stay } \\
\pm \text { SD }\end{array}$ & $\begin{array}{c}\text { Mean } \\
\text { Ventilator } \\
\text { days } \pm \text { SD }\end{array}$ \\
\hline Heat Exhaustion & $2.40 \pm 0.82$ & $2.80 \pm 0.82$ & 0 \\
\hline Heat Stroke & $2.55 \pm 1.34$ & $3.45 \pm 1.64$ & $1.20 \pm 1.64$ \\
\hline
\end{tabular}

\section{DISCUSSION}

Heat-related illness (HRI) due to high ambient temperature and humidity is a common feature in Terai (Southern) region of Nepal during summer. ${ }^{1} \mathrm{HRI}$ particularly heat stroke results in Intensive Care Unit (ICU) admissions ${ }^{2,3,4}$ and is associated with significant morbidity and mortality. ${ }^{5,6}$ There has been studies in marine corps recruits in United Kingdom ${ }^{7}$ and military recruits in United States Army ${ }^{8}$ dealing with risk factors of heat related illness but none has described about its outcome.

In our study, we found that out of the 17 recruits, 12 (70.58\%) was diagnosed as heat exhaustion whereas remaining 5 recruits (29.41\%) was diagnosed as heat stroke. We used SOFA score ${ }^{9,10}$ and APACHE II scoring system ${ }^{11-13}$ to assess the severity of HRI admitted in ICU. They are common scoring systems used in critically ill patients to assess disease severity and predict their outcome in terms of mortality. We found that both the SOFA and APACHE II scores showed high mean score for patients with heat stroke 
$(9.40 \pm 6.10$ and $18.60 \pm 12.81)$ patients than for heat exhaustion $(1 \pm 1.04$ and $2.50 \pm 2.61)$. The predicted mortality rate as shown by both scores for heat stroke was $50 \%$ and $37.88 \%$ where as that for heat exhaustion was $3.50 \%$ and $2.90 \%$. The actual mortality rate observed in our study was $60 \%$ for heat stroke patients (three out of five) and none for heat exhaustion thereby showing that severity of illness were related to mortality. Our result was similar to the retrospective study done by Kalaiselvan $\mathrm{MS}$ et $\mathrm{al}^{2}$ in India where mortality rate was $34 \%$ in nine heat stroke patients among 26 heat related illness patients.

The secondary outcome of our study as observed in terms of mean ICU stay, mean hospital stay and mean stay on ventilator days showed that heat stroke patients had maximum stay as compared to heat exhaustion thereby related to mortality. Neurological $(67.40 \%)$, cardiorespiratory (29.41\%) and coagulation dysfunction (29.41\%) were seen as the main causes of mortality which were similar to that done by Kalaiselvan et al where there was $100 \%$ involvement of neurological system.

\section{CONCLUSION}

Exertional heat related illness is common in young military trainee with heat exhaustion and heat stroke being common causes for ICU admission. Heat stroke has higher mortality rate due to multiple organ dysfunction.

\section{RECOMMENDATIONS}

We recommend larger case control or cohort study involving multiple training centers throughout the country that can tell us the association of various risk factors with outcome.

\section{LIMITATIONS}

The limitation of our study was smaller size of study population thereby not representing recruits from other military training centre of Nepali Army. Multihospital based study must be done to find outcome of heat related illness not only in recruits from Nepali Army but also from Armed Police Force and Nepali Police. Similarly, our study does not tells us about the association of outcome with risk factors.

\section{ACKNOWLEDGEMENTS}

I would like to acknowledge Commandant of military tertiary care hospital for providing me hospital case records, Institutional Research Committee for approving my proposal and all my coauthors for providing their valuable support while conducting this research.

\section{CONFLICT OF INTEREST}

none

\section{REFERENCES}

1. Climate and Health Country Profile - 2015 Nepal [Online]. WHO 2016 [Cited 2018 June 28]; Available from http://www.searo. who.int/entity/water_sanitation/nep_c_h_profile.pdf?ua=1

2. Kalaiselvan MS, Renuka MK, Arunkumar AS. A reterospective study of clinical profile and outcomes of critically ill patients with heat related illness. Indian J Anaesth 2015 Nov; 59(11):715-20. https:// dx.doi.org/10.4103/0019-5049.170030 [PMID: 26755836]

3. Buddhika TB, Senata DP, Vadivel V. Exertional heat stroke in a young military trainee: is it preventable? Military Medical Research 2016; (3): 1-4.https://doi.org/10.1186/s40779-016-0078-1 [PMID:27042327]

4. Andrew PH, Daniel CB, Mark JP. Heat strain during military training activities: The dilemma of balancing force protection and operational capability. m Temperature (Austin) 2016 Apr-Jun; 3(2): 307-317.https://doi.org/ 10.1080/23328940.2016.1156801 PMID: [27857960]

5. Pan ZG, Shao Y, Liu YN, Gu ZT et al. Relationship between early coagulopathy parameters at admission and outcome in patients with severe heat stroke. Zhonghua Wei Zhong Bing JiJu Yi Xue 2013 Dec; 25(12):725-8. https://doi.org/10.3760/cma.j.issn.20954352.2013.12.007 [PMID: 24447352]

6. Azzopardi N, Chetcuti S, Sant J, Pocock J. Acute liver impairment in a Young Healthy Athlete: Hypoxic Hepatitis and Rhabdomyolysis following Heat Stroke. Case Rep Gastroenterol 2012 May; 6(2):5638. https://doi.org/10.1159/000338838. [PMID: 23012616].

7. Pease $\mathrm{S}$, Bouadma L, Kermarrec N, Schortgen F et al. Early organ dysfunction course, cooling time and outcome in classic

heatstroke. Intensive Care Med 2009 Aug; 35(8): 1454-8. https:// doi.org/10.1007/s00134-009-1500-x [PMID:19404610]

8. Kark Ja, Burr PQ, Wenger CB. Exertional heat illness in Marine Corps recruits training. Aviat Space Environ Med. 1996 Apr; 67(4):354-60. PMID [8900989]

9. Bedno SA, Li Y, Han W, Cowan DN. Exertional heat illness among overweight U.S. Army recruits in basic training. Aviat Space Environ Med. 2010 Feb; 81(2):107-11. PMID: [20131650]

10. Khie L, Chuen Y, Nguyen V. Utility of SOFA score, management and outcome of sepsis in Sepsis in South East asia: a multinational multicenter prospective observational study. Journal of Intensive Care 2018; 6:9. https://dx.doi.org/10.1186\%2Fs40560-018-0279-7 [PMID: 29468069\}

11. Saeed S, Majid S, Farhad R. Accuracy of SOFA Score in prediction of 30 day outcome of critically ill patients. Turkish Journal of Emergency Medicine 2016 Nov; 16:146-150. http://dx.doi.org/10.1016/j.tjem. 2016.09.005 [PMID: 27995206]

12. Luciana GC, Paulo AC. The APACHE II measured on patients discharged from Intensive Care Unit in the prediction of mortality. Rev. Latino-Am. Enfermagem 2013 May-June; 21(3):811-819. https://doi.org/10.1590/S0104-11692013000300022 [PMID: 23918029]

13. Abdelbaset $S$, Magda A, Intessar S. Comparison of the mortality prediction of different ICU scoring Systems (APACHE II, SAPS II and SOFA) in a single center ICU subpopulation with acute respiratory distress syndrome. Egyptian Journal of Chest Diseases and Tuberculosis 2015; 64:843-48. https://doi.org/10.1016/j.ejcdt. 2015.05.012 